\title{
EXPERIMENTAL DEFORMATION OF EPIDOTES
}

\author{
E. ILKHANI and P. PAULITSCH \\ Institut für Mineralogie, Technische Hochschule Darmstadt, \\ Darmstadt, FRG
}

(Received February 29, 1974)

Single crystals of epidot were deformed by uniaxial piston-cylinder pressure cell at temperatures from $25^{\circ}-450^{\circ} \mathrm{C}$ and under pressures of $2-12 \mathrm{~kb}$ in order to study the mechanical reaction. New cleavageplanes, translation-planes, kink bands, twin-planes and bending-gliding in form of optical undulation could be expected. In fact, numerous new cleavageplanes, parallel to (110) (111) (101) 101), appeared during these experiments.

The positions of these new planes were strictly connected with the amount of pressure and of the direction of the axial pressure applied to the single crystal. In particular, translation planes were observed parallel to (110) (100) (010), for $T=$ translation plane (100), $t=$ direction of translation [010]. These were found between different pressures from $2-12 \mathrm{~kb}$, and at increasing temperatures between $300^{\circ}$ to $400^{\circ} \mathrm{C}$.

New twin-planes did not appear under these experimental conditions. At the same time, real kink-bands were not produced; on the other hand, zigzag-bands as pseudo-kink-bands were observed in single crystals and twins formed by intersections of segments parallel to (101) and (101), between $2-9 \mathrm{~kb}$ and $300^{\circ}-450^{\circ} \mathrm{C}$.

Optical undulation of $6^{\circ}-20^{\circ}$ was observed at $25^{\circ} \mathrm{C}$ and $3-6 \mathrm{~kb}$, in the second time at $400^{\circ} \mathrm{C}$ and $2 \mathrm{~kb}$. [010] and [100] can be described as experimental bending axes, as also known in natural deformed epidot ${ }^{1}$. It is worth noting that with increasing temperature the angle of the optical axis decreases from $82^{\circ}-72^{\circ}$, depending on both chemical composition and thermal history ${ }^{2}$. These experiments were carried out to higher temperatures until the transition of epidot to anorthite appeared, in agreement with Liou $^{3}$.

\section{ACKNOWLEDGEMENTS}

We acknowledge the support of the German Research Foundation and the technical assistance of Mr. Hochberger and Mrs. Deichmann.

\section{REFERENCES}

1. J. Ladurner, N. Jb. Min. Abh. Bd. 82, (1951).

2. F. Raaz and H. Tertsch, Geom. Kristallographie, (Springer, Wien 1958).

3. J. G. Liou, J. of Petrology 381 (1973). 